
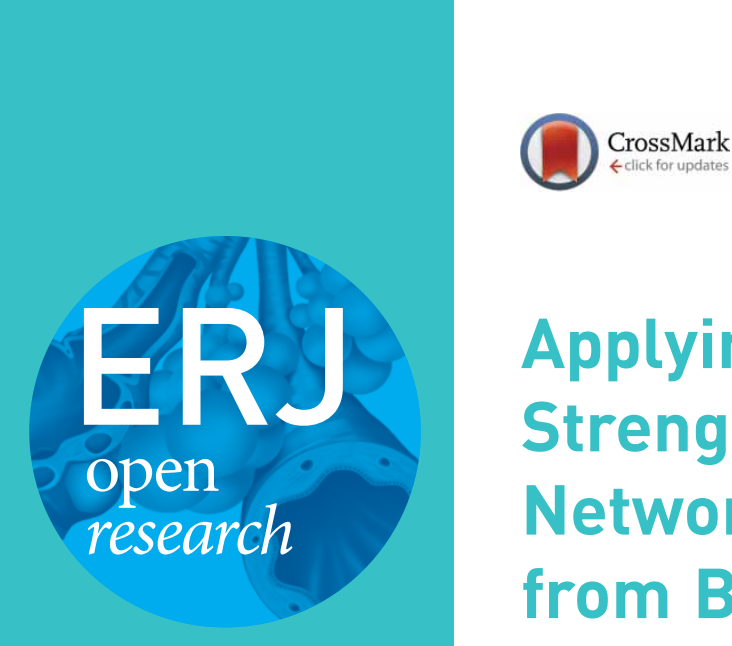

\title{
Applying a Standardized Approach to Strengthen Performances of GeneXpert Networks programme: lessons learned from Burkina Faso, 2019
}

\author{
Riccardo Alagna (1) 1, T. Léon Sawadogo², Elisa Tagliani (1) ${ }^{1}$, Adjima Combary $^{2}$ \\ and Daniela Maria Cirillo (10) 1
}

Affiliations: ${ }^{1}$ IRCCS San Raffaele Scientific Institute, Milan, Italy. ${ }^{2}$ National Tuberculosis Program, Ouagadougou, Burkina Faso.

Correspondence: Riccardo Alagna, IRCCS San Raffaele Scientific Institute, Via Olgettina 58, Milan 20132, Italy. E-mail: alagna.riccardodahsr.it

ABSTRACT GeneXpert scale-up is a historic step in the process of tuberculosis (TB) elimination. However, the global roll-out of the test has highlighted gaps that have limited its impact on the TB care cascade. Here we report the description of an innovative GeneXpert network strengthening tool called Applying a Standardized Approach to Strengthen Performances of GeneXpert Networks (ASAP-GxNet) and highlight results and challenges during implementation of the pilot in Burkina Faso.

ASAP-GxNet is a 6-month competency-based programme involving an innovative GeneXpert assessment tool as well as a series of short courses and projects designed to qualitatively improve the network while strengthening the capacity of the national GeneXpert focal point to oversee the network. Progress of the GeneXpert network is measured before and at the end of the programme and is rated using a star system (0 to 4 stars).

In Burkina Faso, implementation of the ASAP-GxNet programme resulted in improved management of the national GeneXpert network with a $21 \%$ increase in points from the start to the end of the programme.

To our knowledge, ASAP-GxNet is the first programme to give an overall picture of the quality of GeneXpert networks and to investigate performance in terms of management behaviour. ASAP-GxNet has been developed to help national TB programmes coordinate efforts and needs and highlights the expected achievements of the GeneXpert network.

@ERSpublications

Development of ASAP-GxNet programme and lessons learned from pilot implementation in Burkina Faso \#tuberculosis https://bit.ly/338WU3r

Cite this article as: Alagna R, Sawadogo TL, Tagliani E, et al. Applying a Standardized Approach to Strengthen Performances of GeneXpert Networks programme: lessons learned from Burkina Faso, 2019. ERJ Open Res 2020; 6: 00283-2020 [https://doi.org/10.1183/23120541.00283-2020].

Received: 18 May 2020 | Accepted after revision: 28 Aug 2020

Copyright $\odot$ ERS 2020. This article is open access and distributed under the terms of the Creative Commons Attribution Non-Commercial Licence 4.0. 


\section{Introduction}

The World Health Organization (WHO)'s endorsement of the Xpert MTB/RIF assay in 2010 represented a significant breakthrough in TB diagnostics [1]. With the unprecedented need to take advantage of new technologies and improve TB diagnosis, investment in TB laboratory strengthening, including Xpert MTB/ RIF implementation, has also increased. Since 2012, the volume of sales of Xpert MTB/RIF tests has increased dramatically from 1.3 million to nearly 12 million cartridges sold in 2018 solely to the public sector (personal communication). However, massive deployment of Xpert MTB/RIF kits at thousands of sites has highlighted that if these are not implemented with a comprehensive accompanying tools package and within the context of a strengthened health system, diagnostic tests alone are unlikely to produce the expected impact on the TB care cascade [2]. Although performing the Xpert assay is relatively simple, management of the national GeneXpert network is complex, and several settings have reported operational and programmatic challenges associated with assay implementation and routine clinical use [2].

A successful national GeneXpert network requires robust managerial skills that are able to identify strengths and weaknesses as well as efficiently and proactively respond to the network needs. In this context, national GeneXpert focal points play a crucial role in supporting the national TB programme (NTP) to coordinate efforts and needs, to monitor the implementation of national guidelines, and to guarantee continuity of test services in terms of supplies of reagents, training, maintenance, quality assurance and supervision [3]. Despite its importance, in some settings a focal point is not available or has weak managerial skills. This results in several bottlenecks such as delayed procurement and supply of cartridges, lack of regular supervision, inadequate preventive maintenance and delayed replacement of damaged modules. As a result, many national GeneXpert networks are inefficient and underutilised. Although some network assessment tools and training programmes exist, these are not suitable for the broader vision needed to manage a complex network such as the GeneXpert one.

The TB Supranational Reference Laboratory (SRL) of Fondazione Centro San Raffaele of Milan, Italy and the National TB Program of Burkina Faso developed the Applying a Standardized Approach to Strengthen Performances of GeneXpert Networks (ASAP-GxNet) programme to strengthen local managerial skills and conduct a standardised impact assessment of the network. In this article, we describe the tool kit and the results from pilot implementation in Burkina Faso [2].

\section{The ASAP-GxNet competency-based programme}

ASAP-GxNet is a paper and online competency-based training programme composed of an innovative GeneXpert assessment tool along with a series of short courses and work-based projects designed to quantitatively improve the network while strengthening the managerial capacity of the national GeneXpert focal point.

The programme, based on the principles of the Strengthening Laboratory Management Toward Accreditation (SLMTA) training curriculum [4], has been customised to include tools specifically addressing the key elements of the national GeneXpert network. The ASAP-GxNet programme lasts for 6 months and contains two distinct pillars: a standardised assessment tool and a training programme with improvement projects (figure 1).

A baseline assessment using the standardised tool is conducted at the beginning of the programme to identify the strengths and weaknesses of the network. The baseline score is used to identify key priority

\section{Workshop 1}

(1 week)

1) Political and regulatory framework 2) GeneXpert coverage

3) Xpert MTB/RIF (Ultra) Roadmap

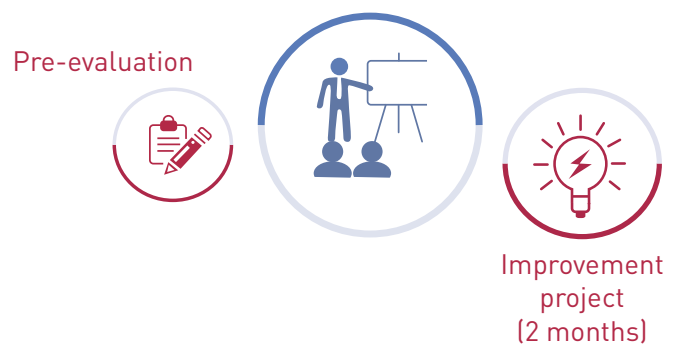

Workshop 2

(1 week)

4) Warranty and calibration

5) Diagnostic data management and connectivity system

6) Supply chain management
Workshop 3

(1 week)

7) Workforce and training

8) Quality assurance and M\&E

9) Budgeting

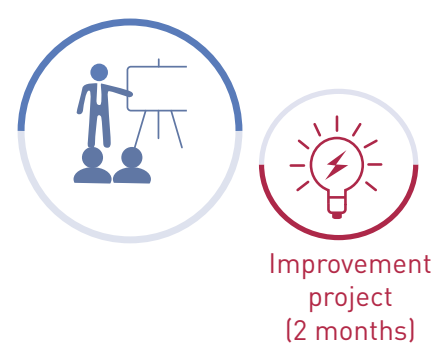

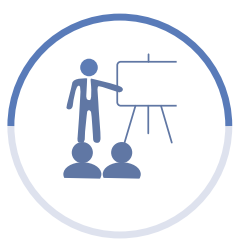

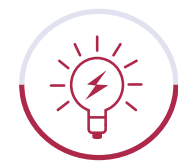

Improvement project

(2 months)

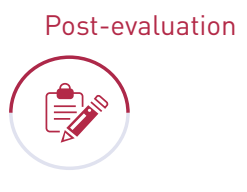

FIGURE 1 Applying a Standardized Approach to Strengthen Performances of GeneXpert Networks (ASAP-GxNet) implementation process. M\&E: montoring and evaluation. 
areas to be addressed during the training curriculum. The training programme is then conducted in a series of three workshops, one every 8 weeks, with improvement projects carried out by the national GeneXpert focal point in the timeframe between workshops. An external mentor supports the national GeneXpert focal point along the entire programme. The primary duties of the external mentor are to conduct an objective evaluation of the national GeneXpert network, to train the national GeneXpert focal point and to guide him/her on the improvement projects.

At the end of the 6-month programme, a final assessment (exit) using the same standardised tool is conducted, and the difference between baseline and exit scores provide a quantitative measure of the impact of the ASAP-GxNet programme.

\section{Standardised assessment tool}

The standardised assessment tool enables the national GeneXpert focal point in collaboration with the NTP to evaluate the GeneXpert network functionality. The assessment tool was developed using an African Society for Laboratory Medicine/Association of Public Health Laboratories Laboratory Network (ASLM/APHL LABNET) scorecard-based approach [5]. It also incorporates critical elements described in the "Practical Guide to Implementing a Quality Assurance System for Xpert MTB/RIF Testing" [6] and includes various checklists and questionnaires developed by the Global Laboratory Initiatives (GLI) [7].

The tool allows assessment of three main "Areas": a) GeneXpert network capacities, b) GeneXpert quality indicators and c) Managerial capacities (table 1). Each "Area" includes a set of "Core capacities" each comprising a number of specific "Components" that are assessed by a series of questions (107 questions in total) (figure 2a). Points are assigned to each "Component" based on the compliance with international recommendations, with each question totalling a maximum of 3 points.

Each "Component" is then highlighted with a specific colour based on the total number of points accumulated, to facilitate the visual identification of the areas that need strengthening (figure $2 \mathrm{~b}$ ). In addition to the colour-coded visualisation of the "Components", a final "Score" based on the total number of points is provided to determine the network "Star rating" - from " 0 stars" ( $0-27$ points, $<20 \%)$ to " 4 stars" (109-135 points, $80-100 \%$ ) (table 1). The assessment tool is distributed to the national or international relevant parties beforehand and completed within 2 days with the external mentor from SRL Milan.

\section{Training programme and improvements projects}

The training programme aims to improve the national GeneXpert focal point capacity in coordinating and accomplishing multiple managerial tasks [8]. The curriculum was developed taking into consideration the key elements of the GLI Training Package "Diagnostic network strengthening and Xpert MTB/RIF (Ultra) implementation" [8]. Based on the principle of "learning by doing", 15 theoretical sessions are combined

TABLE 1 Areas, core capacities and components evaluated by the standardised assessment tool

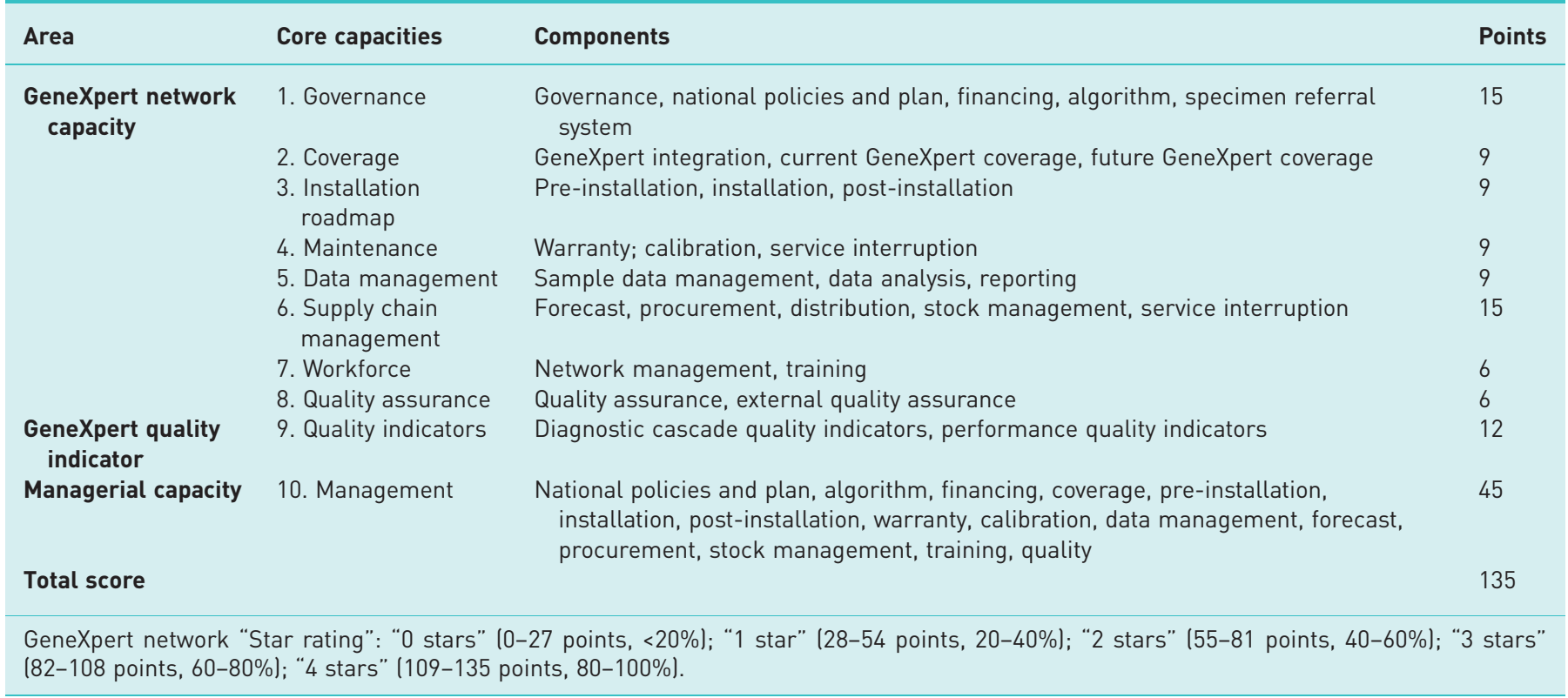


a)

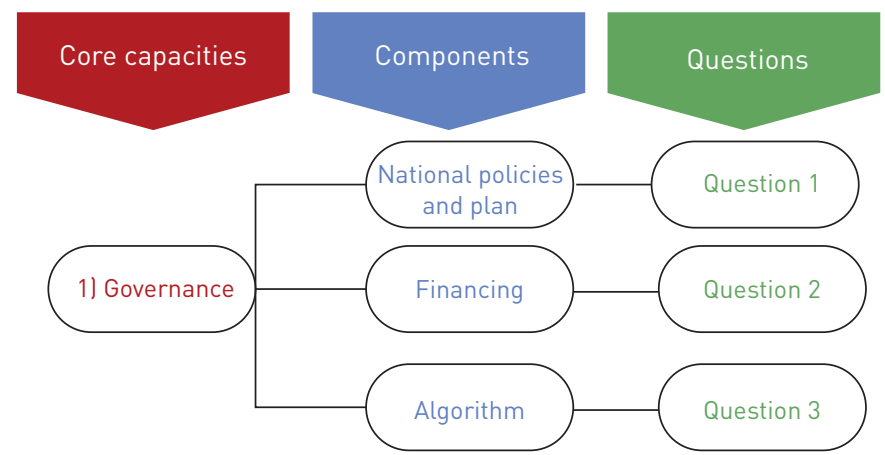

b)

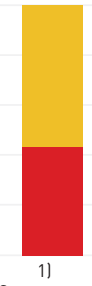

Governance

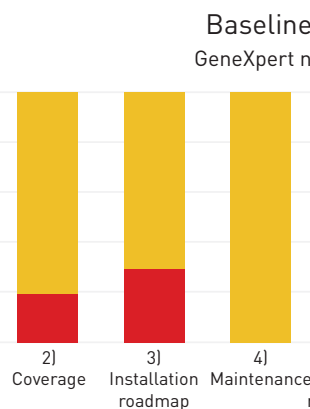

GeneXpert quality indicators
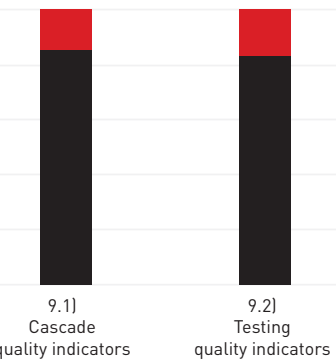

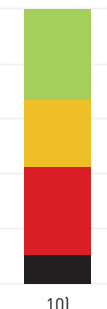

Network

management
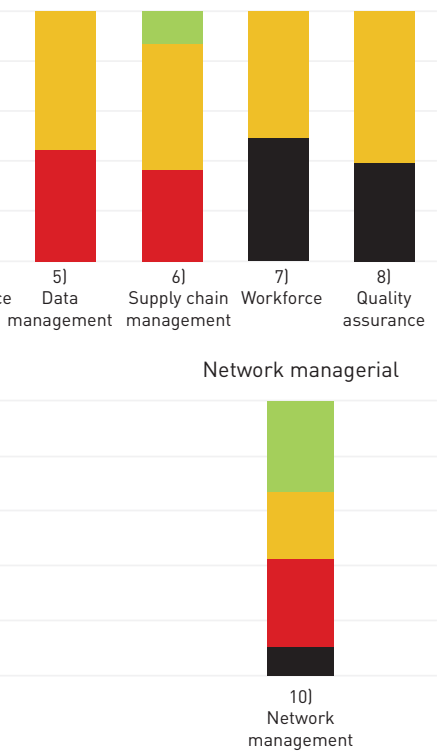

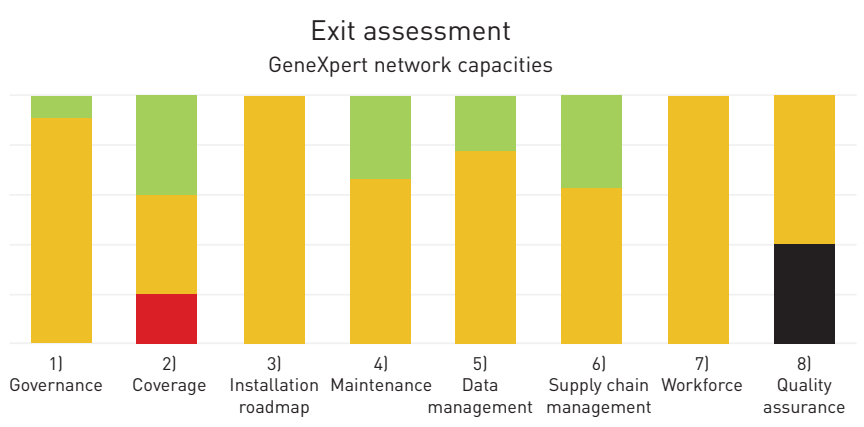

GeneXpert quality indicators

Network managerial
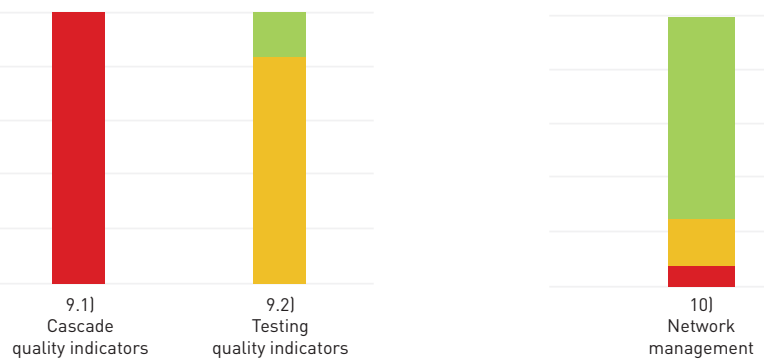

FIGURE 2 Standardised assessment tool structure and colour-coded visualisation of core capacities results. a) Structure of standardised assessment tool with questions defining components and core capacities. b) Colour-coded visualisation of core capacities: Black "0 point", Red “ 1 point”, Yellow “2 points", Green "3 points".

with simulations and hands-on practical exercises. During the 6-month course, three 5-day workshops are organised approximately every 8 weeks, covering the ten "Core capacities". For each workshop, 4 days are dedicated to the analysis and strengthening of two to three "Core capacities", while 5 days are dedicated to developing or updating the related sections of the country GeneXpert operational plan.

In addition to the training curriculum, 15 practical activities are used to allow the national GeneXpert focal point to acquire the new learning concepts and use the ASAP-GxNet tools.

During the training period, improvement projects are carried out by the national GeneXpert focal point to enhance his/her managerial capacity and accountability. A total of 38 improvement projects can be carried out depending on the specific "Core capacities" covered during the workshops and based on gaps identified during the initial network assessment.

\section{Costs associated with the programme}

The ASAP-GxNet programme is available free-of-charge for any country interested in improving the managerial skills of the national GeneXpert focal point and aiming to optimise the use of the available resources to address the gaps of the GeneXpert network through an evidence-based decision-making process. Access to the ASAP-GxNet toolkit is possible through registration to the ASAP-GxNet online application. The online tool aims at guiding users on the utilisation of the ASAP-GxNet and to keep a record of the performance and improvements during the programme. It is important to note that implementation of the ASAP-GxNet programme requires the support of an external mentor with extensive experience in TB laboratory strengthening. Therefore, the main costs are related to technical assistance/mentorship. 


\section{Methods}

Pilot implementation of the ASAP-GxNet programme in Burkina Faso

The Xpert MTB/RIF assay (Cepheid, Sunnyvale, CA, USA) was first introduced in Burkina Faso in June 2013 with the placement of one 4-module GeneXpert machine (GX4) at the TB National Reference Laboratory (NRL). Subsequently, in October 2016, two additional GX4 instruments were installed at two regional laboratories. By the end of 2016, the GeneXpert network was expanded to include an additional 12 GX4 machines resulting in a total of 15 instruments covering all regions in the country.

In 2017, a national GeneXpert focal point was identified and a national Xpert MTB/RIF Operational Plan for the years 2018-2022 was developed and adopted by the National TB Control Programme. According to the national TB diagnostic algorithm, the Xpert MTB/RIF assay was used as the initial diagnostic test for children, people living with HIV, high-risk multidrug-resistant TB patients, prisoners and miners.

The implementation of the ASAP-GxNet programme in Burkina Faso started in March 2019 and ended in December 2019. At that time, the national GeneXpert focal point had little experience in overseeing the GeneXpert network, as no similar programmes existed at national level to strengthen the laboratory managerial capacities of the GeneXpert focal point. The programme started with the initial assessment (i.e. baseline assessment) of the GeneXpert network. The assessment lasted a total of 2 days and was conducted by a mentor from the SRL of Milan.

On the first day, the auditor reviewed the national policies, as well as the national strategies and procedures pertaining to the 10 "Core capacities" of the GeneXpert network, and identified the main areas for improvement and gaps to be addressed based on the scoring system described above. On the second day, the auditor presented the results of the baseline assessment to the NRL/NTP staff, and in conjunction with the country counterpart, developed an action plan for the ASAP-GxNet training programme implementation.

A customised training programme was thus developed to address the specific areas for improvement identified by the baseline assessment. A total of 10 improvement projects were selected to close the identified gaps.

All three workshops were delivered by the same external mentor that conducted the baseline assessment and that supervised the improvement projects. Due to the country's unstable security conditions, a few deviations from the standard 6-month ASAP-GxNet programme had to be applied. Firstly, part of the training was conducted in Burkina Faso and part in Milan, Italy, in the presence of the country national GeneXpert focal point. Secondly, the 5-day workshops were conducted at a 12-week interval, instead of 8 weeks, with the programme lasting a total of 9 months, instead of 6 months. And lastly, the final (i.e. exit) network assessment was conducted remotely by the same external mentor that implemented the programme with the support of the national GeneXpert focal point.

The external mentor reviewed the results of the final assessment, and the overall impact of the ASAP-GxNet programme was discussed with the national TB programme with the official presentation of the results to the national TB laboratory network in December 2019.

\section{Ethical aspects}

Ethics approval was not sought as implementation of ASAP-GxNet was conducted as part of a standard of care and routine public health investigation and response, which did not require a formal ethics review in either Burkina Faso or Italy.

\section{Results}

Upon completion of the ASAP-GxNet programme, all three "Areas" showed a significant improvement, from an overall baseline score of $74 / 135$ points (55\%), corresponding to a two star rating, to $103 / 135$ points $(76 \%)$, corresponding to a three star rating at exit, representing a $21 \%$ overall point increase from baseline to exit. In particular, significant improvements were observed in nine out of 10 "Core capacities", with the only exception of the "Quality assurance" capacity, which remained unvaried (figure 3). At the baseline assessment the average percentage points for all core capacities was $48 \%$ with "Governance", "Coverage", "Maintenance", "Supply chain management" and "Management" above 50\%. As a result of improvements to projects and training (table 2), different grades of progress have been observed at the exit assessment (figure 3). Three "Core capacities" showed an improvement ranging from $34 \%$ to $41 \%$ : "Quality indicators" (from 2/12 points (17\%) to 7/12 points (58\%)), "Data management" (from 4/9 points (44\%) to $7 / 9$ points $(78 \%)$ ) and "Workforce" (from $2 / 6$ points $(33 \%)$ to $4 / 6$ points $(67 \%)$ ). Three "Core capacities" showed an improvement ranging from 20\% to 23\%: "Installation roadmap" (from 4/9 points (44\%) to 6/9 points (67\%)), "Supply chain management" (from $9 / 15$ points (60\%) to $12 / 15$ points $(80 \%)$ ) and "Network management" (from $31 / 45$ points (69\%) to $41 / 45$ points (91\%)). Three "Core capacities" 


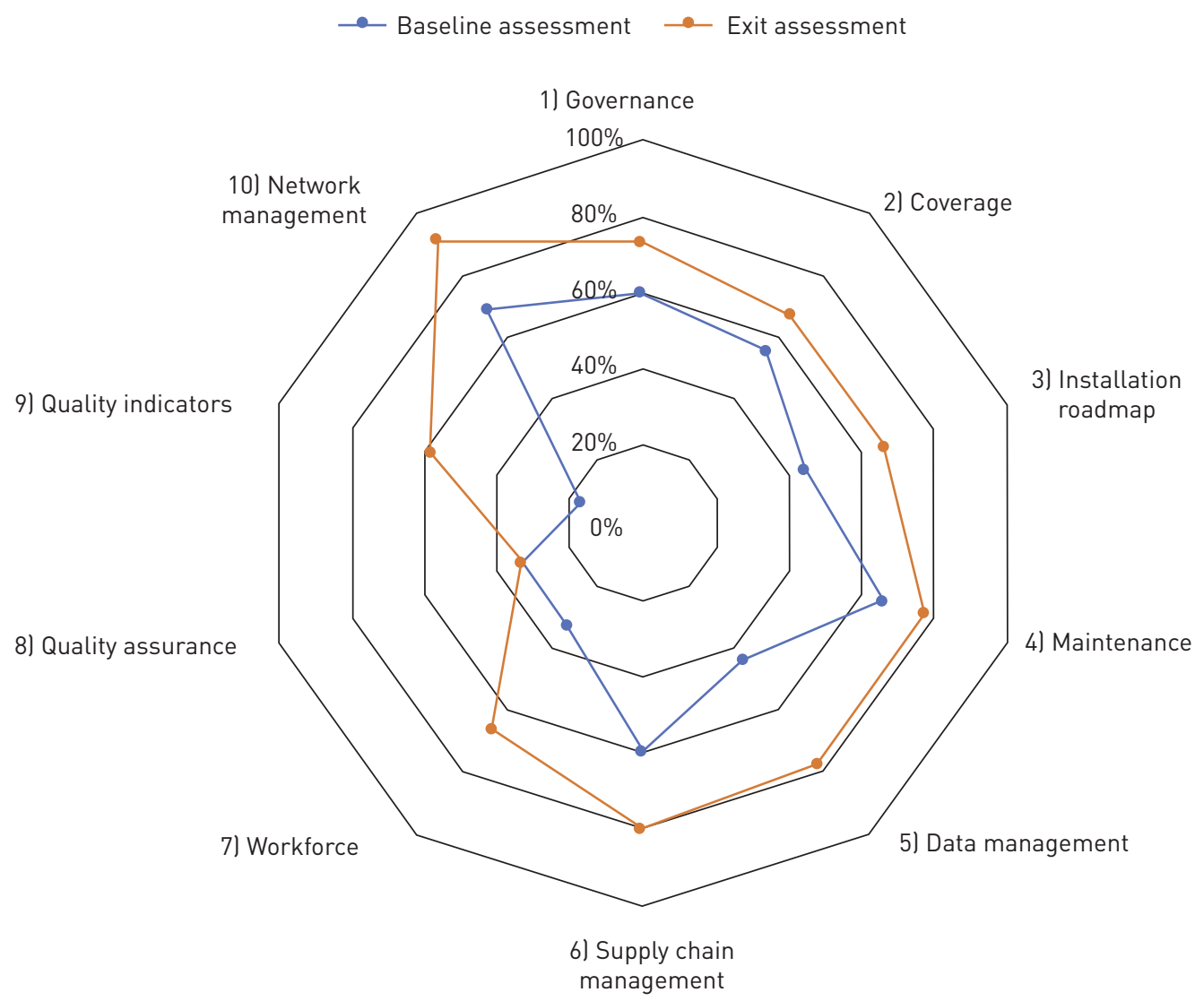

FIGURE 3 Performance of various core capacities, as measured by the Applying a Standardized Approach to Strengthen Performances of GeneXpert Networks (ASAP-GxNet) assessment tool from baseline to exit audit.

showed an improvement ranging from $11 \%$ to $13 \%$ : "Governance" (from $9 / 15$ points (60\%) to 11/15 points (73\%)), "Coverage" (from $5 / 9$ points $(56 \%)$ to $6 / 9$ points $(67 \%)$ ) and "Maintenance" (from 6/9 points $(67 \%)$ to $7 / 9$ points $(78 \%))$.

\section{Discussion}

The present report is a descriptive study based on a pilot implementation of a new approach to strengthen the national GeneXpert network. The implementation of the ASAP-GxNet programme resulted in an improved management of the national GeneXpert network with a $21 \%$ increase in points from start to the end of the programme within a 9-month timeframe. This result was achieved by means of a combination of training activities, targeted improvement projects and high commitment of the national GeneXpert focal point. The experience in Burkina Faso demonstrates that despite its complexity, the national GeneXpert network can be efficiently strengthened by using a structured approach that addresses challenges of various network key components.

The active engagement of the national GeneXpert focal point was crucial to efficiently translate knowledge acquired during the training and improvement projects to real laboratory implementation. The national GeneXpert focal point was also essential in ensuring national TB programme manager buy-in and commitment to rapidly adapt and implement ASAP-GxNet tools. The external mentor ensured that the improvement projects were focused on major weaknesses and achievable in the short term. This approach not only created ownership on improvement results among the NTP team, but also allowed leadership and management skills at the national focal point to be strengthened. For example, most of the improvement projects focused on adapting and implementing tools for overseeing the overall network as well as for developing a sound pluriannual national Xpert MTB/RIF (Ultra) operational plan to facilitate future planning and implementation.

The main programmatic challenges encountered during the implementation of ASAP-GxNet related to a few specific "Core capacities" that required long-term commitment as well as the provision of dedicated funding to support their full implementation and continuation over time. For instance, the "Quality 
TABLE 2 Selection of questions with improved results from baseline to exit assessment and related actions

\begin{tabular}{|c|c|c|c|c|c|c|c|}
\hline Core capacity & $\begin{array}{l}\text { Baseline } \\
\text { points }\end{array}$ & $\begin{array}{l}\text { Exit } \\
\text { points }\end{array}$ & Components & Question & Baseline answer & Exit answer & Actions \\
\hline \multirow[t]{4}{*}{ 1. Governance } & $\begin{array}{l}9 / 15 \\
(60 \%)\end{array}$ & $\begin{array}{l}11 / 15 \\
(91 \%)\end{array}$ & Financing & $\begin{array}{l}\text { Is there any instrument to } \\
\text { estimate costs related to } \\
\text { instrument purchase and } \\
\text { implementation? }\end{array}$ & No tool available & $\begin{array}{l}\text { Tool available and used } \\
\text { Budget aligned with } \\
\text { operational plan }\end{array}$ & $\begin{array}{l}\text { Training on the use of } \\
\text { ASAP-GxNet financing } \\
\text { tool }\end{array}$ \\
\hline & & & & $\begin{array}{l}\text { Are costs for cartridge } \\
\text { procurement estimated? }\end{array}$ & $\begin{array}{l}\text { Detailed cost estimation is available } \\
\text { but not aligned with operational } \\
\text { plan }\end{array}$ & $\begin{array}{l}\text { Detailed cost estimation is } \\
\text { available and aligned with } \\
\text { operational plan }\end{array}$ & $\begin{array}{l}\text { Training on cartridges } \\
\text { quantification }\end{array}$ \\
\hline & & & Algorithm & $\begin{array}{l}\text { Does the algorithm address the } \\
\text { laboratory goals of the End TB } \\
\text { strategy to increase access to } \\
\text { rapid and accurate detection of } \\
\text { TB and to reach universal } \\
\text { access to DST? }\end{array}$ & $\begin{array}{l}\text { The national algorithm incorporates } \\
\text { the use of WHO-approved rapid } \\
\text { diagnostics (WRDs) for all patients } \\
\text { in all high-priority groups (e.g. } \\
\text { those at risk of multidrug-resistant } \\
\text { TB, HIV/TB or paediatric TB) }\end{array}$ & $\begin{array}{l}\text { The national algorithm } \\
\text { incorporates universal access } \\
\text { to WRDs for all patients and } \\
\text { all persons being evaluated } \\
\text { for TB }\end{array}$ & $\begin{array}{l}\text { Improvements not } \\
\text { dependent by } \\
\text { ASAP-GxNet } \\
\text { Following network } \\
\text { analysis country planned } \\
\text { to move to universal use } \\
\text { of Xpert MTB/RIF in } \\
2020\end{array}$ \\
\hline & & & $\begin{array}{l}\text { Specimen referral } \\
\text { system }\end{array}$ & $\begin{array}{l}\text { Is there a national TB specimen } \\
\text { referral and transportation } \\
\text { strategy? }\end{array}$ & $\begin{array}{l}\text { There is a TB specimen referral and } \\
\text { transportation strategy approved }\end{array}$ & $\begin{array}{l}\text { There is an integrated specimen } \\
\text { referral and transportation } \\
\text { strategy approved }\end{array}$ & $\begin{array}{l}\text { Improvements not } \\
\text { dependent by } \\
\text { ASAP-GxNet } \\
\text { Country planned to } \\
\text { move to integrated } \\
\text { specimen referral } \\
\text { system }\end{array}$ \\
\hline 2. Coverage & $\begin{array}{l}5 / 9 \\
(56 \%)\end{array}$ & 6/9 $(67 \%)$ & $\begin{array}{l}\text { Current } \\
\text { GeneXpert } \\
\text { coverage }\end{array}$ & $\begin{array}{l}\text { Is an evidence-based method used } \\
\text { to estimate the future needs of } \\
\text { GeneXpert instruments? }\end{array}$ & $\begin{array}{l}\text { Estimation is based on detailed } \\
\text { evidence }\end{array}$ & $\begin{array}{l}\text { Estimation is based on detailed } \\
\text { evidence } \\
\text { Revised every year (or when } \\
\text { needed) }\end{array}$ & $\begin{array}{l}\text { Improvement projects on } \\
\text { "development of a } \\
\text { document } \\
\text { for identification of } \\
\text { network needs" } \\
\text { Training on the use of } \\
\text { "ASAP-GxNet } \\
\text { assumption tool" }\end{array}$ \\
\hline \multirow[t]{3}{*}{$\begin{array}{l}\text { 3. Installation } \\
\text { roadmap }\end{array}$} & $\begin{array}{l}4 / 9 \\
(44 \%)\end{array}$ & 6/9 $(67 \%)$ & Pre-installation & $\begin{array}{l}\text { Is the selection of new GeneXpert } \\
\text { sites based on standardised } \\
\text { criteria? }\end{array}$ & $\begin{array}{l}\text { New sites are selected by } \\
\text { geographical reasons only }\end{array}$ & $\begin{array}{l}\text { A documented list of criteria, } \\
\text { including geographical, } \\
\text { epidemiological and } \\
\text { infrastructural information, is } \\
\text { described in the Xpert } \\
\text { implementation plan and used } \\
\text { to select new sites }\end{array}$ & $\begin{array}{l}\text { Improvement projects on } \\
\text { "development of a } \\
\text { document for } \\
\text { identification of network } \\
\text { needs" and } \\
\text { training on the use of } \\
\text { ASAP-GxNet matrix } \\
\text { needs tool }\end{array}$ \\
\hline & & & & $\begin{array}{l}\text { Is a standardised checklist } \\
\text { available and used to evaluate } \\
\text { the site prior to installation? }\end{array}$ & $\begin{array}{l}\text { A standardised checklist is available } \\
\text { and used but not detailed }\end{array}$ & $\begin{array}{l}\text { A standardised checklist is } \\
\text { available and used to evaluate } \\
\text { the site prior installation. In line } \\
\text { with FIND checklist template }\end{array}$ & $\begin{array}{l}\text { Improvement project to } \\
\text { revise and update } \\
\text { national document }\end{array}$ \\
\hline & & & Installation & $\begin{array}{l}\text { Is a standardised checklist } \\
\text { available and used to evaluate } \\
\text { the instrument installation? }\end{array}$ & $\begin{array}{l}\text { A standardised checklist is available } \\
\text { and used but not detailed }\end{array}$ & $\begin{array}{l}\text { A standardised checklist is } \\
\text { available and used to evaluate } \\
\text { the site prior installation. In line } \\
\text { with FIND checklist template }\end{array}$ & $\begin{array}{l}\text { Improvement project to } \\
\text { revise and update } \\
\text { national document }\end{array}$ \\
\hline
\end{tabular}




\begin{tabular}{|c|c|c|c|c|c|c|c|}
\hline Core capacity & $\begin{array}{r}\text { Baseline } \\
\text { points }\end{array}$ & $\begin{array}{l}\text { Exit } \\
\text { points }\end{array}$ & Components & Question & Baseline answer & Exit answer & Actions \\
\hline $\begin{array}{l}\text { 3. Installation } \\
\text { roadmap, } \\
\text { continued }\end{array}$ & & & Post-installation & $\begin{array}{l}\text { Is a standardised checklist } \\
\text { available and used to evaluate } \\
\text { GeneXpert sites? }\end{array}$ & $\begin{array}{l}\text { A standardised checklist is available } \\
\text { and used but not detailed }\end{array}$ & $\begin{array}{l}\text { A standardised checklist is } \\
\text { available and used to evaluate } \\
\text { the site. In line with FIND } \\
\text { checklist template }\end{array}$ & $\begin{array}{l}\text { Improvement project to } \\
\text { revise and update } \\
\text { national document }\end{array}$ \\
\hline \multirow[t]{3}{*}{ 4. Maintenance } & $\begin{array}{l}6 / 9 \\
(67 \%)\end{array}$ & $\begin{array}{l}7 / 9 \\
(78 \%)\end{array}$ & Warranty & $\begin{array}{l}\text { Is there a mechanism in place to } \\
\text { monitor GeneXpert instrument } \\
\text { repairs at testing sites? }\end{array}$ & $\begin{array}{l}\text { Yes, but the current mechanism is not } \\
\text { functional }\end{array}$ & $\begin{array}{l}\text { Yes, but it functions well only at } \\
\text { some testing sites }\end{array}$ & $\begin{array}{l}\text { Improvement project on } \\
\text { implementation of Xpert } \\
\text { tracking tool }\end{array}$ \\
\hline & & & Calibration & $\begin{array}{l}\text { Are all GeneXpert instruments } \\
\text { calibrated every year? }\end{array}$ & $\begin{array}{l}\text { Some GeneXpert instruments are } \\
\text { calibrated every year with delay }\end{array}$ & $\begin{array}{l}\text { All GeneXpert instruments are } \\
\text { calibrated in due time }\end{array}$ & $\begin{array}{l}\text { Improvement project on } \\
\text { implementation of Xpert } \\
\text { tracking tool } \\
\text { Training on calibration } \\
\text { plan and strategy }\end{array}$ \\
\hline & & & $\begin{array}{l}\text { Service } \\
\quad \text { interruption }\end{array}$ & $\begin{array}{l}\text { Is a back-up plan (including SOPs) } \\
\text { available in case of service } \\
\text { interruption due to equipment } \\
\text { failure for handling specimens } \\
\text { during these times, } \\
\text { identification of referral } \\
\text { laboratory for testing and } \\
\text { referral procedures? }\end{array}$ & $\begin{array}{l}\text { Only ad hoc back-up plan takes place } \\
\text { during equipment failure }\end{array}$ & $\begin{array}{l}\text { Back-up plan (including SOPs) is } \\
\text { available but not applied for } \\
\text { handling specimens during } \\
\text { service interruption due to } \\
\text { equipment failure }\end{array}$ & $\begin{array}{l}\text { Improvement project to } \\
\text { develop a back-up plan } \\
\text { for all GeneXpert sites }\end{array}$ \\
\hline \multirow[t]{4}{*}{$\begin{array}{l}\text { 5. Data } \\
\text { management }\end{array}$} & $\begin{array}{l}4 / 9 \\
(44 \%)\end{array}$ & $\begin{array}{l}7 / 9 \\
(78 \%)\end{array}$ & $\begin{array}{l}\text { Sample data } \\
\text { management }\end{array}$ & $\begin{array}{l}\text { Is there any connectivity system for } \\
\text { Xpert MTB/RIF(-ULTRA) testing } \\
\text { in place? }\end{array}$ & No connectivity system available & $\begin{array}{l}\text { Connectivity system is in place, } \\
\text { but it only partially covers the } \\
\text { network }\end{array}$ & $\begin{array}{l}\text { Improvement project to } \\
\text { select connectivity } \\
\text { system supplier } \\
\text { Connectivity system } \\
\text { implementation } \\
\text { on-going }\end{array}$ \\
\hline & & & Data analysis & $\begin{array}{l}\text { Are there adequately trained } \\
\text { personnel, software and/or tool } \\
\text { that receives laboratory data } \\
\text { from all levels, analyses the } \\
\text { data and generates reports? }\end{array}$ & $\begin{array}{l}\text { There are trained personnel but not } \\
\text { adequate software or tools to } \\
\text { analyse and report Xpert MTB/ } \\
\text { RIF-(ULTRA) data }\end{array}$ & $\begin{array}{l}\text { There are trained personnel, } \\
\text { adequate software or tools to } \\
\text { analyse data. Complete } \\
\text { reports are generated on } \\
\text { regular basis }\end{array}$ & $\begin{array}{l}\text { Improvement project to } \\
\text { implement ASAP-GxNet } \\
\text { quarterly report data } \\
\text { collection } \\
\text { Training through the } \\
\text { ASAP-GxNet } \\
\text { programme }\end{array}$ \\
\hline & & & & $\begin{array}{l}\text { Are statistical data collected, } \\
\text { analysed and used for } \\
\text { decision-making purposes and } \\
\text { shared within NTP? }\end{array}$ & $\begin{array}{l}\text { Only a few Xpert MTB/RIF-(ULTRA) } \\
\text { indicators are collected and } \\
\text { analysed }\end{array}$ & $\begin{array}{l}\text { A comprehensive list of Xpert } \\
\text { MTB/RIF-(ULTRA) indicators } \\
\text { are collected and analysed } \\
\text { and effectively used for } \\
\text { decision-making purposes }\end{array}$ & $\begin{array}{l}\text { Improvement project to } \\
\text { implement quality } \\
\text { indicators } \\
\text { Training quality } \\
\text { indicators }\end{array}$ \\
\hline & & & Reporting & $\begin{array}{l}\text { Is there an electronic system that } \\
\text { enables reporting of diagnostic } \\
\text { data to local and national } \\
\text { programme? }\end{array}$ & $\begin{array}{l}\text { Electronic reporting for GeneXpert } \\
\text { network improvement purposes is } \\
\text { functional in reference laboratories } \\
\text { only }\end{array}$ & $\begin{array}{l}\text { Electronic reporting for } \\
\text { GeneXpert network } \\
\text { improvement purposes is } \\
\text { functional at all levels and } \\
\text { analysed for a limited range of } \\
\text { purposes }\end{array}$ & $\begin{array}{l}\text { Improvement project to } \\
\text { implement ASAP-GxNet } \\
\text { quarterly report data } \\
\text { collection }\end{array}$ \\
\hline
\end{tabular}




\begin{tabular}{|c|c|c|c|c|c|c|c|}
\hline Core capacity & $\begin{array}{r}\text { Baseline } \\
\text { points }\end{array}$ & $\begin{array}{l}\text { Exit } \\
\text { points }\end{array}$ & Components & Question & Baseline answer & Exit answer & Actions \\
\hline \multirow[t]{2}{*}{$\begin{array}{l}\text { 6. Supply chain } \\
\text { management }\end{array}$} & $\begin{array}{l}9 / 15 \\
(60 \%)\end{array}$ & $\begin{array}{l}12 / 15 \\
(80 \%)\end{array}$ & Forecast & $\begin{array}{l}\text { Is forecast of Xpert MTB/ } \\
\text { RIF-(ULTRA) needs done based } \\
\text { on past and projected } \\
\text { consumption? }\end{array}$ & No system and methodology are used & $\begin{array}{l}\text { Past and projected consumption } \\
\text { is used to forecast Xpert MTB/ } \\
\text { RIF-(ULTRA) needs. Forecasts } \\
\text { are revised on a yearly basis }\end{array}$ & $\begin{array}{l}\text { Training on cartridges } \\
\text { forecast }\end{array}$ \\
\hline & & & $\begin{array}{l}\text { Service } \\
\quad \text { interruption }\end{array}$ & $\begin{array}{l}\text { Have testing facilities provided } \\
\text { uninterrupted GeneXpert testing } \\
\text { services, with no disruption due } \\
\text { to cartridge stockouts (or since } \\
\text { last assessment)? }\end{array}$ & $\begin{array}{l}\text { Some testing facilities (more than half } \\
\text { of total number) have faced at least } \\
\text { one instance in the last year of } \\
\text { testing service interruption due to } \\
\text { cartridge stockouts }\end{array}$ & $\begin{array}{l}\text { Some testing facilities (less than } \\
\text { half of total number) have } \\
\text { faced at least one instance in } \\
\text { the last year of testing service } \\
\text { interruption due cartridge } \\
\text { stockouts }\end{array}$ & $\begin{array}{l}\text { Not dependent by } \\
\text { ASAP-GxNet training } \\
\text { Improvement projects to } \\
\text { develop a back-up plan } \\
\text { for GeneXpert machine } \\
\text { troubleshooting }\end{array}$ \\
\hline \multirow[t]{3}{*}{ 7. Workforce } & $\begin{array}{l}2 / 6 \\
(33 \%)\end{array}$ & $\begin{array}{l}4 / 6 \\
(67 \%)\end{array}$ & $\begin{array}{l}\text { Network } \\
\text { management }\end{array}$ & $\begin{array}{l}\text { Does the national GeneXpert focal } \\
\text { point have adequate managerial } \\
\text { knowledge and skills (plan, } \\
\text { organise, lead and control) to } \\
\text { oversee the GeneXpert network? }\end{array}$ & $\begin{array}{l}\text { The focal point has adequate } \\
\text { knowledge of the network but } \\
\text { limited capacity to plan and } \\
\text { organise different tasks of the } \\
\text { network }\end{array}$ & $\begin{array}{l}\text { The focal point has adequate } \\
\text { knowledge and skills to } \\
\text { oversee the network }\end{array}$ & $\begin{array}{l}\text { Training through the } \\
\text { ASAP-GxNet } \\
\text { programme }\end{array}$ \\
\hline & & & & $\begin{array}{l}\text { Does the national GeneXpert focal } \\
\text { point have a list of daily/ } \\
\text { monthly/annual routine work } \\
\text { tasks? }\end{array}$ & $\begin{array}{l}\text { No list of routine work tasks is } \\
\text { available }\end{array}$ & $\begin{array}{l}\text { A comprehensive list of daily/ } \\
\text { monthly/annual routine work } \\
\text { tasks is available and } \\
\text { performed in due time }\end{array}$ & $\begin{array}{l}\text { Training through the } \\
\text { ASAP-GxNet } \\
\text { programme }\end{array}$ \\
\hline & & & & $\begin{array}{l}\text { Does the GeneXpert focal point } \\
\text { use and update the Xpert } \\
\text { tracking or similar tool to } \\
\text { optimise network management? }\end{array}$ & No & $\begin{array}{l}\text { The Xpert tracking or similar tool } \\
\text { is used, data exploited and } \\
\text { regularly updated }\end{array}$ & $\begin{array}{l}\text { Improvement project on } \\
\text { implementation of Xpert } \\
\text { tracking tool }\end{array}$ \\
\hline 8. Quality & $\begin{array}{l}2 / 6 \\
(33 \%)\end{array}$ & $\begin{array}{l}2 / 6 \\
(33 \%)\end{array}$ & Quality assurance & $\begin{array}{l}\text { Is a standardised checklist } \\
\text { available and used to evaluate } \\
\text { GeneXpert sites? }\end{array}$ & $\begin{array}{l}\text { A standardised checklist is available } \\
\text { and used but not complete }\end{array}$ & $\begin{array}{l}\text { A standardised checklist is } \\
\text { available and used to evaluate } \\
\text { the site. In line with FIND } \\
\text { checklist template }\end{array}$ & $\begin{array}{l}\text { Improvement project to } \\
\text { revise and update } \\
\text { national document }\end{array}$ \\
\hline \multirow[t]{7}{*}{$\begin{array}{l}\text { 9. Quality } \\
\text { indicators }\end{array}$} & $\begin{array}{l}2 / 12 \\
\quad(17 \%)\end{array}$ & $\begin{array}{l}7 / 12 \\
\quad(58 \%)\end{array}$ & $\begin{array}{l}\text { Diagnostic } \\
\text { cascade quality } \\
\text { indicator }\end{array}$ & $\begin{array}{l}\text { End TB Strategy laboratory target } \\
\text { indicator } 1 \\
\text { End TB Strategy laboratory target } \\
\text { indicator } 2 \\
\text { End TB Strategy laboratory target } \\
\text { indicator } 3\end{array}$ & No data available & $\begin{array}{l}\text { Data available target not } \\
\text { achieved } \\
\text { Target achievable in a } \\
\text { reasonable time frame }\end{array}$ & $\begin{array}{l}\text { Improvement project on } \\
\text { implementation of Xpert } \\
\text { tracking tool and data } \\
\text { collection/analysis tool }\end{array}$ \\
\hline & & & & $\begin{array}{l}\text { End TB Strategy laboratory target } \\
\text { indicator } 4\end{array}$ & & $\begin{array}{l}\text { Data available, target not } \\
\text { achieved }\end{array}$ & \\
\hline & & & & $\begin{array}{l}\text { End TB Strategy laboratory target } \\
\text { indicator } 7\end{array}$ & & $\begin{array}{l}\text { Target achievable in a } \\
\text { reasonable time frame }\end{array}$ & \\
\hline & & & & $\begin{array}{l}\text { End TB Strategy laboratory target } \\
\text { indicator } 8\end{array}$ & & $\begin{array}{l}\text { Data available, target not } \\
\text { achieved }\end{array}$ & \\
\hline & & & Testing quality & Data completeness & & All data available, full analysis & \\
\hline & & & indicators & Error rate & & $\begin{array}{l}\text { Media rate below the target. One } \\
\text { or more sites with rate above } \\
\text { the target }\end{array}$ & \\
\hline & & & & Invalid rate & & & \\
\hline
\end{tabular}




\section{TABLE 2 Continued}

\begin{tabular}{|c|c|c|c|c|c|c|c|}
\hline Core capacity & $\begin{array}{l}\text { Baseline } \\
\text { points }\end{array}$ & $\begin{array}{l}\text { Exit } \\
\text { points }\end{array}$ & Components & Question & Baseline answer & Exit answer & Actions \\
\hline \multirow{3}{*}{$\begin{array}{l}\text { 9. Quality } \\
\text { indicators, } \\
\text { continued }\end{array}$} & & & & No result rate & & $\begin{array}{l}\text { Media rate below the target. No } \\
\text { site with rate above the target }\end{array}$ & \\
\hline & & & & $\begin{array}{l}\text { Specimens with a result reported } \\
\text { within } 24 \mathrm{~h}\end{array}$ & & $\begin{array}{l}\text { Results reported in } 24 \mathrm{~h} \text { in some } \\
\text { sites }\end{array}$ & \\
\hline & & & & $\begin{array}{l}\text { Media of maximum Xpert testing } \\
\text { capacity per month }\end{array}$ & & $\begin{array}{l}\text { Number of tests slightly below } \\
\text { the maximum Xpert testing } \\
\text { capacity (2-3 tests per day) }\end{array}$ & \\
\hline \multirow[t]{6}{*}{$\begin{array}{l}\text { 10. Network } \\
\text { Management }\end{array}$} & $\begin{array}{l}31 / 45 \\
(69 \%)\end{array}$ & $\begin{array}{l}41 / 45 \\
(91 \%)\end{array}$ & $\begin{array}{l}\text { National policies } \\
\text { and plan }\end{array}$ & $\begin{array}{l}\text { Does the GeneXpert focal point } \\
\text { revise the Xpert implementation } \\
\text { plan every year? }\end{array}$ & $\begin{array}{l}\text { Not done (due to reasons directly } \\
\text { linked or not to GeneXpert focal } \\
\text { point capacities) }\end{array}$ & 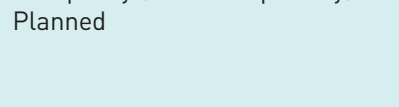 & $\begin{array}{l}\text { Training through the } \\
\text { ASAP-GxNet } \\
\text { programme }\end{array}$ \\
\hline & & & Algorithm & $\begin{array}{l}\text { Does the GeneXpert focal point } \\
\text { monitor, through data } \\
\text { GeneXpert sites, the adherence } \\
\text { of national diagnostic } \\
\text { algorithm? }\end{array}$ & & $\begin{array}{l}\text { Yes, done and actions are taken } \\
\text { for those sites not adherent }\end{array}$ & \\
\hline & & & Installation & $\begin{array}{l}\text { Have you developed and/or } \\
\text { updated a standardised training } \\
\text { (1-day) materials? }\end{array}$ & & Yes done & \\
\hline & & & $\begin{array}{l}\text { Data } \\
\text { management }\end{array}$ & $\begin{array}{l}\text { Are information from GeneXpert } \\
\text { sites routinely updated on Xpert } \\
\text { tracking tool? }\end{array}$ & & Yes done & \\
\hline & & & & $\begin{array}{l}\text { Are periodic data from GeneXpert } \\
\text { sites routinely collected and } \\
\text { analysed? }\end{array}$ & & Yes done & \\
\hline & & & Quality & $\begin{array}{l}\text { Does the GeneXpert focal point } \\
\text { periodically analyse quality } \\
\text { indicators and results for all } \\
\text { GeneXpert sites? }\end{array}$ & & Yes done & \\
\hline
\end{tabular}


assurance" core capacity required the implementation of an external quality assurance programme, which included the provision of a proficiency panel testing. While different options currently exist [6], the enrolment in a proficiency programme through an external provider is hampered by the country's lack of sufficient and dedicated funding. On the other hand, in-country preparation of the panels requires extensive planning and technical capacity to initiate the programme. The "Governance" core capacity pertains to aspects related to the national laboratory strategic plan, national diagnostic algorithm and specimen referral system, all activities that require long-term planning and alignment with a national TB programme funding cycle to ensure improvement. The "Coverage" core capacity aims at evaluating current and future diagnostic needs and assessing the integration of the GeneXpert platform into diagnostic services other than TB. This requires a complex feasibility study and a robust collaborative environment among different disease programmes to enable effective integration and utilisation of these devices [9-11].

Additional challenges affecting the implementation of the programme related to the numerous tasks and duties of the national GeneXpert focal point, who over the course of the programme was also appointed as Head of the National TB Reference Laboratory, thus limiting the amount of time that could be devoted to improvement projects and an implementation roadmap.

\section{Conclusion}

Strengthening capacities to manage the national GeneXpert network and to identify service weaknesses is crucial to ensure the delivery of high-quality services and continuity of care for patients. Lessons learned from early implementation suggest that the ASAP-GxNet programme has the potential to improve the management of a complex network in a relatively short timeframe and to raise awareness at country level on the importance of developing the skills and capacity to manage a diagnostic network efficiently. Alignment of ASAP-GxNet implementation with the Global Fund grant cycle may significantly improve the capacity to implement those activities that require dedicated funding. In this context, the selection of improvement projects is critical to ensure that activities are feasible with available resources. Although the experience in Burkina Faso demonstrates that the ASAP-GxNet programme has the potential to improve capacity to deliver continuous provision of quality diagnostic services, multiple cycles of the programme need to be carried out to result in a sustained long-term impact.

Acknowledgements: The authors are grateful to the National Tuberculosis Programme Team of Burkina Faso and Virginia Quaresima from IRCSS San Raffaele Scientific Institute (Milan, Italy).

Conflict of interest: None declared.

Support statement: ASAP-GxNet is supported by the Stop TB Partnership's TB REACH initiative, and is funded by the Government of Canada and the Bill \& Melinda Gates Foundation.

\section{References}

1 World Health Organization. Policy Statement: Automated Real-Time Nucleic Acid Amplification Technology for Rapid and Simultaneous Detection of Tuberculosis and Rifampicin Resistance: Xpert MTB/RIF. Policy Statement. Geneva, World Health Organization, 2011.

2 Albert H, Nathavitharana RR, Isaacs C, et al. Development, roll-out and impact of Xpert MTB/RIF for tuberculosis: what lessons have we learnt and how can we do better? Eur Respir J 2016; 48: 516-525.

3 Alagna R, Sawadogo TL, Combary A, et al. ASAP-GxNet project in Burkina Faso: fulfil country capacity gaps to ensure efficient utilisation of GeneXpert instruments in tuberculosis care and cascade. ERJ Open Res 2019; 5: 00150-2018.

4 Yao K, Maruta T, Luman ET, et al. The SLMTA programme: transforming the laboratory landscape in developing countries. Afr J Lab Med 2014; 3: 194

5 Ondoa P, Datema T, Keita-Sow MS, et al. A new matrix for scoring the functionality of national laboratory networks in Africa: introducing the LABNET scorecard. Afr J Lab Med 2016; 5: 498.

6 Global Laboratory Initiative. Practical Guide to Implementing a Quality Assurance System for Xpert MTB/RIF Testing. http://stoptb.org/wg/gli/pgiqas.asp Date last accessed: 2020. Datelast update: 2019.

7 Global Laboratory Initiative. Xpert MTB/RIF Training Package. www.stoptb.org/wg/gli/trainingpackages.asp Date last accessed: 2020. Date last updated: 2019.

8 Global Laboratory Initiative. GLI Training Package: Diagnostic Network Strengthening and Xpert MTB/RIF (Ultra) Implementation. http://www.stoptb.org/wg/gli/TrainingPackage_XPERT_MTB_RIF_Ultra.asp Date last accessed: 2020. Date last update: 2017.

9 Ndlovu Z, Fajardo E, Mbofana E, et al. Multidisease testing for HIV and TB using the GeneXpert platform: a feasibility study in rural Zimbabwe. PLoS One 2018; 13: e0193577.

10 Bassett IV, Forman LS, Govere S, et al. Test and Treat TB: a pilot trial of GeneXpert MTB/RIF screening on a mobile HIV testing unit in South Africa. BMC Infect Dis 2019; 19: 110.

11 Nash M, Ramapuram J, Kaiya R, et al. Use of the GeneXpert tuberculosis system for HIV viral load testing in India. Lancet Glob Health 2017; 5: e754-e755. 